\title{
The new heterologous fibrin sealant in combination with low-level laser therapy (LLLT) in the repair of the buccal branch of the facial nerve
}

\author{
Daniela Vieira Buchaim ${ }^{1}$ - Antonio de Castro Rodrigues ${ }^{2}$ - Rogerio Leone Buchaim ${ }^{2}$. \\ Benedito Barraviera $^{3}$ • Rui Seabra Ferreira Junior ${ }^{3}$ - Geraldo Marco Rosa Junior ${ }^{4}$. \\ Cleuber Rodrigo de Souza Bueno ${ }^{4}$ - Domingos Donizeti Roque ${ }^{1}$ - Daniel Ventura Dias ${ }^{5}$. \\ Leticia Rossi Dare $^{5} \cdot$ Jesus Carlos Andreo $^{2}$
}

Received: 5 November 2015 / Accepted: 11 April 2016/Published online: 25 April 2016

(C) Springer-Verlag London 2016

\begin{abstract}
This study aimed to evaluate the effects of lowlevel laser therapy (LLLT) in the repair of the buccal branch of the facial nerve with two surgical techniques: end-to-end epineural suture and coaptation with heterologous fibrin sealant. Forty-two male Wistar rats were randomly divided into five groups: control group (CG) in which the buccal branch of the facial nerve was collected without injury; (2) experimental group with suture (EGS) and experimental group with fibrin (EGF): The buccal branch of the facial nerve was transected on both sides of the face. End-to-end suture was performed on the right side and fibrin sealant on the left side; (3) Experimental group with suture and laser (EGSL) and experimental group with fibrin and laser (EGFL). All animals underwent the same surgical procedures in the EGS and EGF groups, in combination with the application of LLLT (wavelength of $830 \mathrm{~nm}, 30 \mathrm{~mW}$ optical power output of potency, and energy density of $6 \mathrm{~J} / \mathrm{cm}^{2}$ ). The animals of the five groups were euthanized at 5 weeks post-surgery and 10 weeks post-surgery. Axonal sprouting was observed in the distal
\end{abstract}

Daniela Vieira Buchaim

danibuchaim@usp.br

1 Human Morphophysiology (Anatomy), Faculty of Medicine, University of Marilia (UNIMAR), Marilia, SP, Brazil

2 Department of Biological Sciences (Anatomy), Bauru School of Dentistry, University of São Paulo, Bauru, SP, Brazil

3 Center for the Study of Venoms and Venomous Animals (CEVAP), São Paulo State University (UNESP_-Univ Estadual Paulista), Botucatu, São Paulo State, Brazil

4 University of the Sacred Heart, Bauru, SP, Brazil

5 Federal University of Pampa-UNIPAMPA, Uruguaiana, RS, Brazil stump of the facial nerve in all experimental groups. The observed morphology was similar to the fibers of the control group, with a predominance of myelinated fibers. In the final period of the experiment, the EGSL presented the closest results to the CG, in all variables measured, except in the axon area. Both surgical techniques analyzed were effective in the treatment of peripheral nerve injuries, where the use of fibrin sealant allowed the manipulation of the nerve stumps without trauma. LLLT exhibited satisfactory results on facial nerve regeneration, being therefore a useful technique to stimulate axonal regeneration process.

Keywords Facial nerve $\cdot$ Fibrin sealant $\cdot$ Low-level laser therapy $\cdot$ Nerve regeneration $\cdot$ Peripheral nerve injury

\section{Introduction}

Facial palsy, with the loss of facial expression, is a social problem that leads to significant deterioration in quality of life $[1,2]$. It can compromise any verbal communication conveyed by facial expressions which is essential to social relationships, for example, a spontaneous and dynamic smile that is essential in community interaction $[3,4]$.

Facial traumas are common and can result from various factors such as motor vehicle accidents, falls and accidental injuries, injuries from sharp objects, and firearms. They can also result from iatrogenic causes and postoperative chronic injuries that lead to fractures and lacerations of the face, resulting in facial nerve injuries that compromise the tone and dynamics of facial expression [4-6].

Lesions involving peripheral nerves are classified according to the degree of nerve impairment and structures involved 
in neuropraxia, axonotmesis, and neurotmesis [7]. Peripheral nerves, when damaged, are capable of regenerating by themselves or with the aid of surgical techniques depending on the type of lesion. Thus, in the case of neurological injuries of the neurotmesis lesions, where the nerve underwent complete section of the axon and its surroundings, surgical repair becomes necessary [8-10].

End-to-end epineural neurorrhaphy is the technique of choice in lesions characterized by complete section of the nerve or when the continuous injury has a minor extent. In these types of injuries where there is tissue loss, the stumps can be approximated without exaggerated tension and then sutured, presenting a greater chance of recovery $[11,12]$.

However, despite the end-to-end epineural suture technique being a widely used method in neurological injuries of neurotmesis lesions of minor extent, it requires microsurgery techniques, as well as excessive manipulation of the tissues for the approximation of the stumps $[13,14]$. The fibrin sealant is being used in the recovery of peripheral nerve injuries, with the purpose of minimizing the disadvantages of the epineural suture technique [15].

The new heterologous fibrin sealant, derived from snake venom, was developed with the primary objective of producing a sealant without the use of human blood components, hence preventing the transmission of infectious diseases [16]. It is a biological and biodegradable plasma-derived concentrate for topical use, whose mechanism of action is similar to the last stage of physiological coagulation. The clot formed by the sealant is a physiological compound found in tissue repair, and this makes it different from other types of sealants which present toxicity and high fibrin formation [17]. Fibrin sealant presents its own biological properties, being versatile in different clinical settings, including in combination with conventional suture techniques $[16,18]$.

Low-level laser therapy (LLLT) is an effective ally in the treatment of peripheral nerve regeneration. Its use started in the 1980s and is the subject of many recent studies, for it has shown an immediate protective effect, reducing the formation of scar tissue on the wound and significantly increasing the axonal outgrowth and myelination [19-21]. Moreover, it has the ability to reduce the migration of mononuclear cells, leading to a decrease in the edema area, analgesia, and antiinflammatory action, promoting a more rapid regeneration [22].

Considering its frequency and the functional and social unease that facial nerve injury produces, the objective of this study was to evaluate the effects of LLLT in the repair of lesions of buccal branch of the facial nerve by two surgical techniques: end-to-end epineural suture and coaptation with heterologous fibrin sealant.

\section{Materials and methods}

\section{Fibrin sealant}

Heterologous fibrin sealant derived from snake venom was kindly supplied by the State University of São Paulo (UNESP), more specifically its Center for the Study of Venoms and Venomous Animals (CEVAP); its constituents and instructions for use are stated in its patents (registration numbers BR1020140114327 and BR1020140114360). At the time of use, the components were previously thawed, reconstituted, mixed, and applied according to the following protocol: The first bottle had fibrinogen obtained from buffalo blood $(5 \mu \mathrm{l})$, the second contained calcium chloride $(2 \mu \mathrm{l})$, and the last bottle had a thrombin-like fraction $(1 \mu \mathrm{l})$, totaling $8 \mu \mathrm{l}[16,23-26]$.

\section{Study design}

The experimental procedures performed were approved by the Ethics Committee on Teaching and Research in animals of the Bauru School of Dentistry, University of São Paulo (São Paulo, Brazil), by way of Protocol 034/2011.

A total of 42 male Wistar rats (Rattus norvegicus), 60 days in age, weighing an average of $250 \mathrm{~g}$ were used. All animals were kept in appropriate boxes and received water and food "ad libitum, " with no movement restrictions, a 12-h regime of light and dark, obtained with the use of a "timer" in the animal maintenance room, as well as exposure to an approximate temperature of $22{ }^{\circ} \mathrm{C}$.

The animals were randomly divided into a control group and four experimental groups, as follows:

1. Control group (CG): Consisting of 10 animals, where the buccal branch of the facial nerve was collected at 95 and 130 days of life (five animals in each period), which were the euthanasia periods of the experimental groups.

2. Experimental group with suture (EGS) and experimental group with fibrin (EGF): Consisting of 16 animals in which the buccal branch of the facial nerve was transected on both sides of the face, but on the right side, end-to-end epineural suture was performed, whereas on the left side, fibrin sealant was used for coaptation of the extremities. Eight animals, in each period, were euthanized at 95 days of life (5 weeks post-surgery) and at 130 days of life (10 weeks post-surgery).

3. Experimental group with suture and laser (EGSL) and experimental group with fibrin and laser (EGFL) associated with the low-level laser therapy: Consisting of 16 animals that underwent the same surgical procedures as EGS and EGF, in combination with low-level laser application. Eight animals, in each period, were euthanized at 95 days of life ( 5 weeks post-surgery) and at 130 days of life (10 weeks post-surgery). 


\section{Surgical procedures}

For the surgical procedure, at 60 days of age, in experimental groups (EGS, EGF, EGSL, and EGFL), all animals were weighed and underwent general anesthesia through an intramuscular injection of the anesthetic Zoletil $50^{\circledR}$ (Virbac of Brazil), which contains a 1:1 ratio $(125: 125 \mathrm{mg})$ of tiletamine hydrochloride and zolazepam hydrochloride $(0.15 \mathrm{ml} / \mathrm{kg} / \mathrm{IM})$. After the adoption of antisepsis techniques for the procedure, trichotomy was performed on all animals, and they were placed in lateral decubitus position.

An incision in the face with a scalpel blade no. 15 (approximately from the tragus of the ear toward the labial commissure) was performed with subsequent dessication up to the exposure of the buccal branch of the facial nerve, which was cut with straight tip scissors, without removing fragments displayed on the surgical microscope (DFV, Brazil).

In the EGS group, end-to-end epineural suture with nylon 10-0 monofilament (Ethicon ${ }^{\circledR}$, Johnson \& Johnson, Brazil) was performed on the right side of the face. In the EGF group, after the same procedures described, the nerve stumps were approximated and coaptated with fibrin sealant. To end the procedure, the skin was sutured using 4-0 silk thread (Ethicon ${ }^{\circledR}$, Johnson \& Johnson, Brazil).

In the EGSL and EGFL groups, the animals went through the same surgical procedures, but the application of continuous pulse laser was applied.

\section{Laser irradiation}

In the EGSL and EGFL groups, laser therapy with continuous pulse via gallium-aluminum-arsenide laser (GaAlAs, Laserpulse IBRAMED ${ }^{\circledR}$, Brazil) was applied on the animals. The protocol was applied using a laser pen at three different points in the surgical area, on the skin surface, with a wavelength of $830 \mathrm{~nm}$, with $30 \mathrm{~mW}$ optical power output of potency, energy density of $6 \mathrm{~J} / \mathrm{cm}^{2}$, beam area of $0.116 \mathrm{~cm}^{2}$, power density of $258.6 \mathrm{~mW} / \mathrm{cm}^{2}$, and exposure time of $24 \mathrm{~s}$ (per point). The laser source had been previously tested to certify the dose. The laser therapy applications were performed 1 day after surgery, and in the postoperative period, three times a week for a total of 5 weeks [27-29].

\section{Processing for optical microscopy and transmission electron microscopy}

After 5 and 10 weeks of the surgical procedure [30, 31], in each period, five animals in the control group and eight animals from each experimental group were euthanized with an "overdose" of anesthesia to collect the intact buccal branch of the facial nerve from the control group and the distal stump from the buccal branch of the facial nerve in animals from the experimental groups.
The samples were set in Karnovsky's fixative for $24 \mathrm{~h}$. For the optical microscopy $(\mathrm{OM})$ and transmission electron microscopy (TEM) processing, routine laboratory procedures including HistoResin (Leica Mycrosistems ${ }^{\circledR}$, Germany) mounting media were used. After inclusion, ultrathin cross sections $(5 \mu \mathrm{m})$ of the fascicles were obtained and stained with $1 \%$ toluidine blue, combined with $1 \%$ sodium borate.

\section{Morphometric and statistical analysis}

The following measurements were undertaken: area and diameter of the fibers, area and diameter of the axon, and area and thickness of the myelin sheath.

The measurements were obtained through images captured using an Olympus ${ }^{\circledR}$ microscope (Japan), and photographs were taken with a coupled digital camera (Olympus ${ }^{\circledR}$ DP 71 , Japan). Quantitative analysis was performed using the Image Pro-Plus 6.0 program (Media Cybernetics ${ }^{\circledR}$, USA). Statistical analysis was performed using variance analysis (ANOVA) with Tukey's post-test. The level of significance for the comparisons was predetermined at $p<0.05$.

\section{Results}

\section{Morphological evaluation (optical microscopy)}

In animals from the $C G$ at 95 days of age, myelinated fibers with regular placement and diameters were observed. In the experimental groups, the nerve fibers presented irregular placement, with myelinated fibers of heterogeneous diameters. In all groups, unmyelinated fibers were also observed (Fig. 1).

In animals at 130 days of age from the CG, myelinic fibers with regular placement and diameters were observed. In the experimental groups, myelin fibers were heterogeneous and had an irregular placement (Fig. 2).

\section{Morphological evaluation (electron microscopy)}

The TEM confirmed, in both periods analyzed, the presence of regenerated axons, mostly myelinic, consisting of regular features in the $\mathrm{CG}$ and irregular in experimental groups (Figs. 3 and 4). The presence of collagen fibers and Schwann cell nuclei were observed (Fig. 4).

\section{Morphometric and statistical evaluation}

In animals at 95 days of age, there was a significant difference between the CG and all experimental groups, as well as between EGF and EGSL, with relation to the area and diameter of the fibers. In the variable area of the axon, there was a significant difference between all groups. There was a 
Fig. 1 Animals with 95 days. Microscopic aspect of the buccal branch of the facial nerve in groups: a CG, b EGS, c EGF, d EGSL, and e EGFL. Presence of regenerated myelinic (white arrow) and unmyelinic (white star) nerve fibers
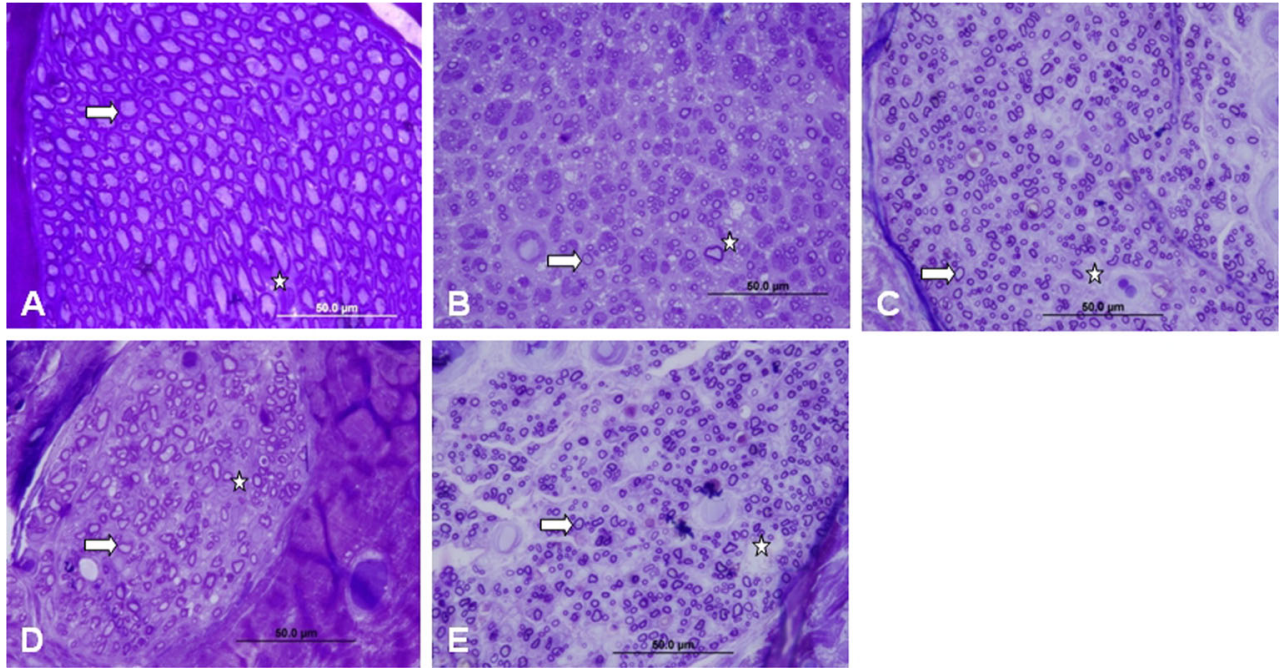

significant difference in the diameter of the axon between the CG and all experimental groups and between the EGF and all other groups. A significant difference was observed between the $C G$ and all experimental groups with respect to the area of the myelin sheath. A significant difference in the myelin sheath thickness was observed when comparing the CG and EGF groups, as well as the CG and EGFL groups (Table 1).

In animals at 130 days of age, there was a significant difference between the CG and EGS and between CG and EGF and also between CG and EGFL with regard to the fiber area. There were significant differences between the CG and EGF as well as between CG and EGFL and also between EGF and EGSL with respect to the diameter of the fiber. In the variable area of the axon, there was no significant difference between the $\mathrm{CG}$ and the experimental groups. A significant difference in the diameter of the axon was observed between the CG and the EGS, EGF and EGFL groups (Table 2).

\section{Discussion}

The aim of the present study was to compare the repair of the buccal branch of the facial nerve by means of two techniques: end-to-end suture, considered a gold standard for the recovery of peripheral nerve injuries, and the coaptation technique of joining the injured stumps through the use of new heterologous fibrin sealant. In addition, it sought to verify the influence of low-level laser in the repair process.

End-to-end suture is described as an effective technique (gold standard) for axonal regeneration in cases of the neurotmesis lesions which do not exhibit tissue loss and where the stumps can be approximated without exaggerated pressure $[11,12]$. In the two repair techniques which were used in this experiment, surgery was performed visually amplification in a surgical microscope to improve coaptation of the fragments. Failure to correct adaptation of the nerve stumps leads to the
Fig. 2 Animals with 130 days. Microscopic aspect of the buccal branch of the facial nerve in groups: a CG, b EGS, c EGF, d EGSL, and e EGFL. Presence of regenerated myelinic nerve fibers (white arrow)
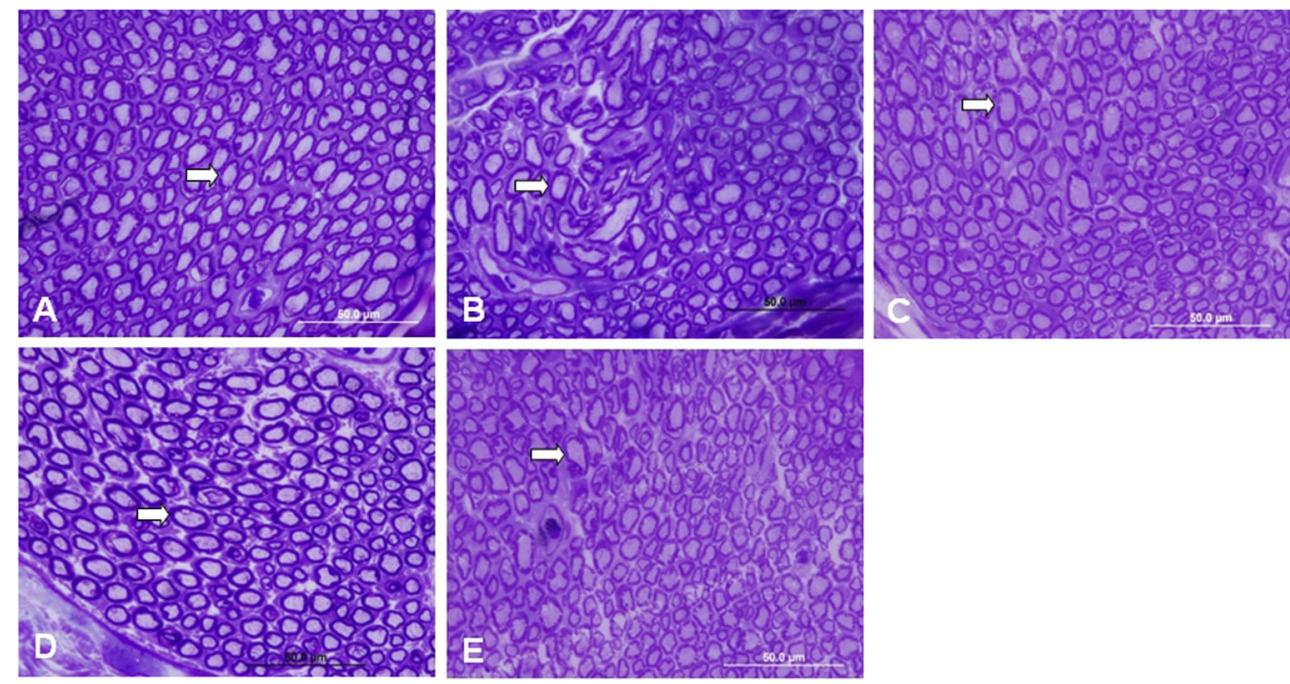
Fig. 3 Animals with 95 days Electron microscopy of the buccal branch of the facial nerve in groups: a CG, b EGS, c EGF, d EGSL, and e EGFL. Presence of regenerated myelinic (white arrow) and unmyelinic (white star) nerve fibers
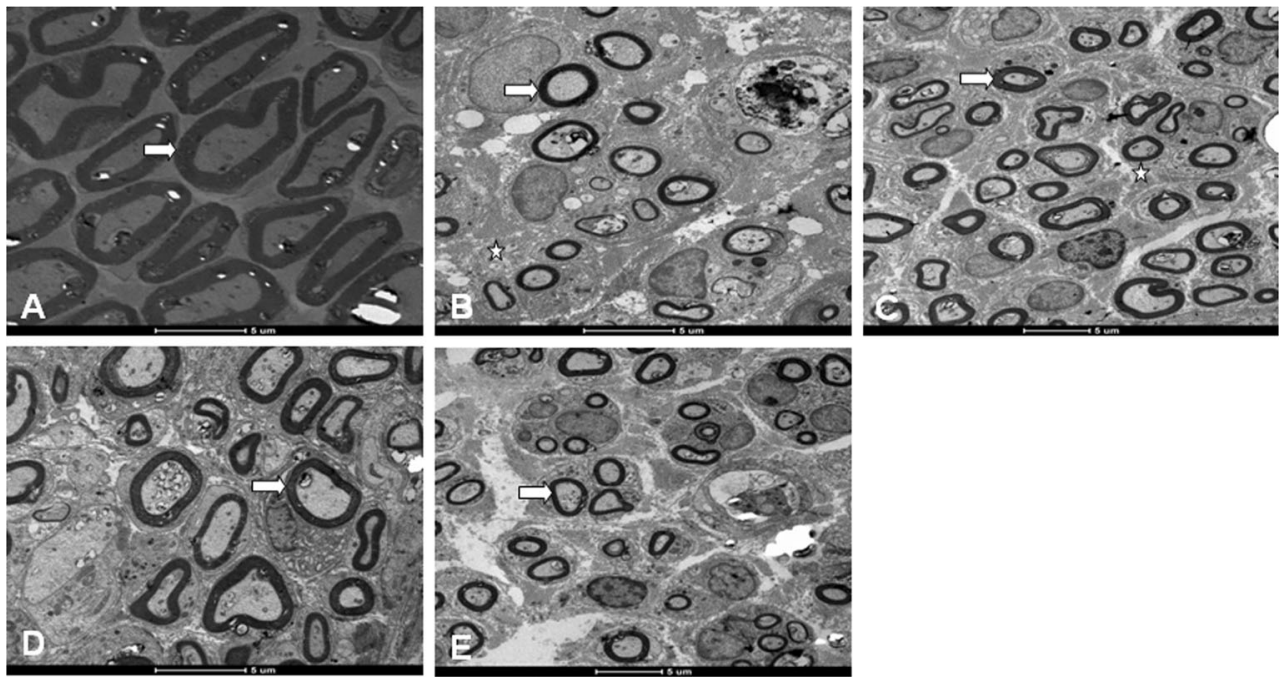

formation of granulation tissue blocking axonal regeneration. Microsurgical magnification and more precise knowledge of anatomy have improved the results, decreasing unwanted fascicular disorientation [32].

In this study, the buccal branch of the facial nerve was sectioned without removing fragments, allowing the joining of the stumps and the performance of end-to-end suture with satisfactory results, given that this technique is mostly used in cases of injuries with minor extension that do not present tissue loss. In search of an alternative technique, or one that can be combined with suture, fibrin sealants have been shown to be effective in repair, with easier implementation, and also resulting in less time for surgery $[33,34]$.

Comparing the use of epineural suture (EGS) with fibrin sealant (EGF), at 130 days of the experiment, there was no significant difference between the variables measured, indicating that fibrin sealant is an effective method in the repair process of peripheral nerves and that during the experimental surgical procedures, it presented flexibility, versatility, and good adhesive property [16, 26, 29, 35].

In the morphological analysis of the experimental groups in general, myelin fibers occurred with predominance, with irregular placement and diameters in all groups, features that are characteristic of the nerve regeneration process. In the period of 10 weeks, the myelin fibers showed better organization of the fascicle in relation to the prior 5-week period, in which an evolutionary stage in the experimental groups was observed $[36,37]$. There was no evidence of inflammatory response to the sealant or foreign body reaction [38, 39].

In the morphometric analysis, within 10 weeks after surgery, taking the $\mathrm{CG}$ as reference (nerve control), the EGSL presented the closest results (no significant difference) in all variables measured, except in axon area. The speed of propagated nerve impulses is directly related to the nerve fiber diameter and myelin sheath. The fastest nerve fibers have larger diameters and are myelinated [40]. The fact that the CG and
Fig. 4 Animals with 130 days. Electron microscopy of the buccal branch of the facial nerve in groups: a CG, b EGS, c EGF, d EGSL, and e EGFL. Presence of regenerated myelinic (white arrow) and unmyelinic (white star) nerve fibers, Schwann cell (white triangle), and collagen fibers (white ellipse)
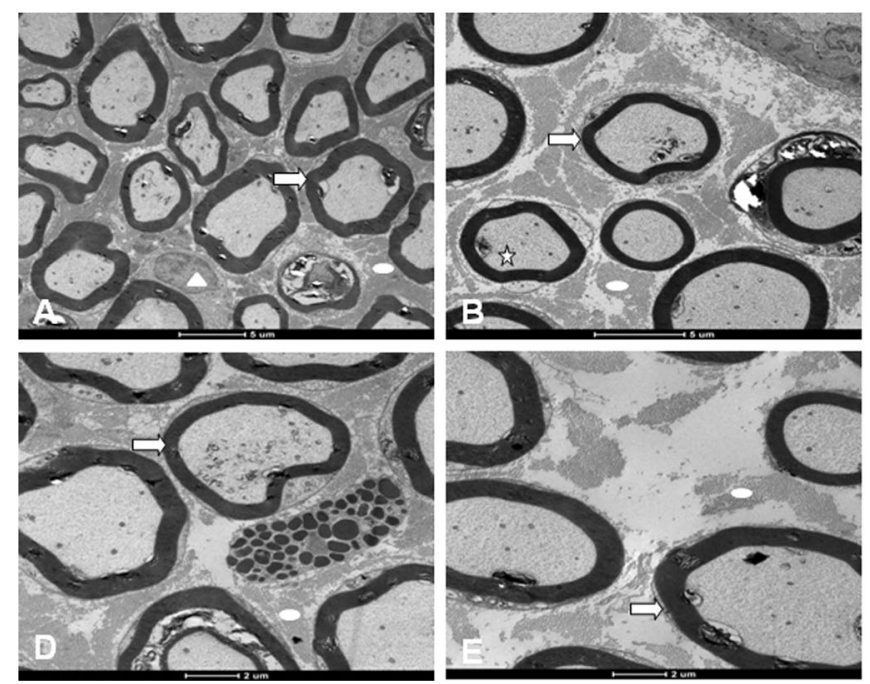

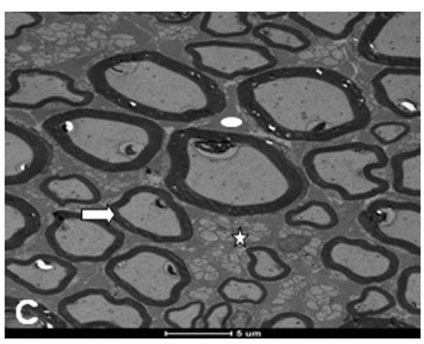

黑 Springer 
Table 1 Animals with 95 days of age

\begin{tabular}{lllllll}
\hline & $\begin{array}{l}\text { Fiber area } \\
\left(\mu \mathrm{m}^{2}\right)\end{array}$ & $\begin{array}{l}\text { Axon area } \\
\left(\mu \mathrm{m}^{2}\right)\end{array}$ & $\begin{array}{l}\text { Fiber } \\
\text { diameter } \\
(\mu \mathrm{m})\end{array}$ & $\begin{array}{l}\text { Axon } \\
\text { diameter } \\
(\mu \mathrm{m})\end{array}$ & $\begin{array}{l}\text { Myelin } \\
\text { sheath area } \\
\left(\mu \mathrm{m}^{2}\right)\end{array}$ & $\begin{array}{l}\text { Myelin sheath } \\
\text { thinkness }(\mu \mathrm{m})\end{array}$ \\
\hline $\mathrm{CG}$ & $21.83 \pm 1.90 \mathrm{a}$ & $7.36 \pm 0.48 \mathrm{a}$ & $5.50 \pm 0.24 \mathrm{a}$ & $3.29 \pm 0.15 \mathrm{a}$ & $14.47 \pm 1.84 \mathrm{a}$ & $2.20 \pm 0.39 \mathrm{a}$ \\
$\mathrm{EGS}$ & $12.91 \pm 1.00 \mathrm{~b}$ & $5.06 \pm 0.31 \mathrm{~b}$ & $4.25 \pm 0.23 \mathrm{~b}$ & $2.57 \pm 0.16 \mathrm{~b}$ & $7.85 \pm 0.81 \mathrm{~b}$ & $1.68 \pm 0.34 \mathrm{ac}$ \\
$\mathrm{EGF}$ & $11.94 \pm 0.83 \mathrm{bc}$ & $3.89 \pm 0.24 \mathrm{c}$ & $3.94 \pm 0.18 \mathrm{bc}$ & $2.32 \pm 0.14 \mathrm{c}$ & $8.05 \pm 0.83 \mathrm{~b}$ & $1.61 \pm 0.16 \mathrm{bc}$ \\
EGSL & $13.98 \pm 0.80 \mathrm{bd}$ & $5.60 \pm 0.36 \mathrm{~d}$ & $4.43 \pm 0.27 \mathrm{bd}$ & $2.70 \pm 0.11 \mathrm{~b}$ & $8.38 \pm 0.80 \mathrm{~b}$ & $1.73 \pm 0.37 \mathrm{ac}$ \\
EGFL & $13.22 \pm 0.66 \mathrm{~b}$ & $4.43 \pm 0.30 \mathrm{e}$ & $4.14 \pm 0.22 \mathrm{~b}$ & $2.61 \pm 0.11 \mathrm{~b}$ & $8.79 \pm 0.78 \mathrm{~b}$ & $1.53 \pm 0.32 \mathrm{bc}$ \\
\hline
\end{tabular}

The morphometry of the nerve fibers in terms of the different measurements (mean and standard deviation) was performed comparing the control group (CG), experimental group with suture (EGS), experimental group with fibrin (EGF), experimental group with suture and laser (EGSL), and experimental group with fibrin and laser (EGFL). Different lowercase letters indicate significant differences among the groups by means of the analysis of variance (ANOVA), followed by Tukey's test $(p<0.05)$ the experimental groups had statistically similar results in the cited measures showed that the two repair techniques analyzed are efficient, with satisfactory results in relation to the degree of maturation of fibers [13].

In the transmission electron microscopy, within a 10week period, the myelinated fibers showed better organization in the nerve fascicle in relation to the 5-week period. The microscope also showed the presence of oblique and longitudinal collagen fibers, indicating a random orientation of the fibers in the regenerating tissue. Collagen fibers are important in the regeneration process because they provide biological support for cell growth, increasing differentiation of various cell types $[41,42]$.

Regarding the use of LLLT, the most effective laser application with regard to wavelength, energy density, exposure time, and pulsed or continuous wave is still controversial, but its use is suggested to facilitate the nerve regeneration $[27,43]$. Based in this study, on the statistical data, similar results were observed in most measured variables, when comparing EGS to EGSL and EGF to EGFL in both periods, but with mean values almost always favorable with laser therapy.

This finding suggests that despite the satisfactory results obtained in clinical and experimental research, there is a need to carry out further studies to obtain the confirmation of the effects of laser therapy on the repair of peripheral nerves, as well as the standardization of the applied protocols and evaluation parameters [19, 20, 22, 29, 44].

\section{Conclusion}

Both techniques analyzed were effective in the treatment of peripheral nerve injuries, because they allow for a sprouting of the myelinated nerve fibers in the distal stump, where the sealant allowed the coaptation of the stumps without trauma to the nerve fibers. Low-level laser therapy exhibited satisfactory results on facial nerve regeneration, being therefore a useful technique to stimulate axonal regeneration process.
Table 2 Animals with 130 days of age

\begin{tabular}{lllllll}
\hline & $\begin{array}{l}\text { Fiber area } \\
\left(\mu \mathrm{m}^{2}\right)\end{array}$ & $\begin{array}{l}\text { Axon area } \\
\left(\mu \mathrm{m}^{2}\right)\end{array}$ & $\begin{array}{l}\text { Fiber diameter } \\
(\mu \mathrm{m})\end{array}$ & $\begin{array}{l}\text { Axon } \\
\text { diameter } \\
(\mu \mathrm{m})\end{array}$ & $\begin{array}{l}\text { Myelin } \\
\text { sheath area } \\
\left(\mu \mathrm{m}^{2}\right)\end{array}$ & $\begin{array}{l}\text { Myelin } \\
\text { sheath } \\
\text { thinkness } \\
(\mu \mathrm{m})\end{array}$ \\
\hline $\mathrm{CG}$ & $50.19 \pm 2.66 \mathrm{a}$ & $18.92 \pm 1.12 \mathrm{a}$ & $11.34 \pm 1.31 \mathrm{a}$ & $6.84 \pm 0.42 \mathrm{a}$ & $31.27 \pm 3.55 \mathrm{a}$ & $4.50 \pm 1.09 \mathrm{a}$ \\
$\mathrm{EGS}$ & $45.43 \pm 3.17 \mathrm{bc}$ & $14.93 \pm 0.91 \mathrm{~b}$ & $10.02 \pm 0.80 \mathrm{ac}$ & $6.06 \pm 0.45 \mathrm{bc}$ & $30.50 \pm 2.94 \mathrm{a}$ & $3.96 \pm 0.95 \mathrm{a}$ \\
EGF & $42.92 \pm 1.99 \mathrm{bc}$ & $14.36 \pm 1.25 \mathrm{~b}$ & $8.91 \pm 0.52 \mathrm{bc}$ & $5.58 \pm 0.44 \mathrm{bc}$ & $28.56 \pm 3.03 \mathrm{a}$ & $3.33 \pm 0.35 \mathrm{a}$ \\
EGSL & $46.21 \pm 2.17 \mathrm{ac}$ & $15.05 \pm 0.91 \mathrm{~b}$ & $10.23 \pm 0.70 \mathrm{ad}$ & $6.12 \pm 0.33 \mathrm{ac}$ & $31.15 \pm 2.25 \mathrm{a}$ & $4.11 \pm 0.66 \mathrm{a}$ \\
EGFL & $44.01 \pm 2.38 \mathrm{bc}$ & $14.71 \pm 1.62 \mathrm{~b}$ & $9.48 \pm 0.85 \mathrm{bc}$ & $5.84 \pm 0.51 \mathrm{bc}$ & $29.29 \pm 3.72 \mathrm{a}$ & $3.63 \pm 0.79 \mathrm{a}$ \\
\hline
\end{tabular}

The morphometry of the nerve fibers in terms of the different measurements (mean and standard deviation) was performed comparing the control group (CG), experimental group with suture (EGS), experimental group with fibrin (EGF), experimental group with suture and laser (EGSL), and experimental group with fibrin and laser (EGFL). Different lowercase letters indicate significant differences among the groups by means of the analysis of variance (ANOVA), followed by Tukey's test $(p<0.05)$ 


\section{Compliance with ethical standards}

Conflict of interest The authors declare that they have no conflict of interest.

\section{References}

1. Dougall A, Fiske J (2008) Access to special care dentistry, part 9. Special care dentistry services for older people. Br Dent J 205(8): 421-434

2. Ozsoy U, Hizay A, Demirel BM, Ozsoy O, Bilmen Sarikcioglu S, Turhan M, Sarikcioglu L (2011) The hypoglossal-facial nerve repair as a method to improve recovery of motor function after facial nerve injury. Ann Anat 193(4):304-313

3. Tong Y, Chen J, Ji Q (2010) A unified probabilistic framework for spontaneous facial action modeling and understanding. IEEE Trans Pattern Anal Mach Intell 32(2):258-273

4. Fattah A, Borschel GH, Zuker RM (2011) Reconstruction of facial nerve injuries in children. J Craniofac Surg 22(3):782-788

5. Hundeshagen G, Szameit K, Thieme H, Finkensieper M, Angelov DN, Guntinas-Lichius O, Irintchev A (2013) Deficient functional recovery after facial nerve crush in rats is associated with restricted rearrangements of synaptic terminals in the facial nucleus. Neuroscience 248:307-318

6. Thorén H, Snäll J, Salo J, Suominen-Taipale L, Kormi E, Lindqvist C, Törnwall J (2010) Occurrence and types of associated injuries in patients with fractures of the facial bones. J Oral Maxillofac Surg 68(4):805-810

7. Seddon HJ (1943) Three types of nerve injury. Brain 66:237-288

8. Friedman AH, Elias WJ, Midha R (2009) Introduction: peripheral nerve surgery-biology, entrapment, and injuries. Neurosurg Focus 26(2), E1

9. Félix SP, Pereira Lopes FR, Marques SA, Martinez AM (2013) Comparison between suture and fibrin glue on repair by direct coaptation or tubulization of injured mouse sciatic nerve. Microsurgery 33(6):468-477

10. Sinis N, Geuna S, Viterbo F (2014) Translational research in peripheral nerve repair and regeneration. Biomed Res Int 2014: 381426

11. Johnson EO, Soucacos PN (2008) Nerve repair: experimental and clinical evaluation of biodegradable artificial nerve guides. Injury 39(Suppl 3):S30-S36

12. Ray WZ, Mackinnon SE (2010) Management of nerve gaps: autografts, allografts, nerve transfers, and end-to-side neurorrhaphy. Exp Neurol 223(1):77-85

13. Attar BM, Zalzali H, Razavi M, Ghoreishian M, Rezaei M (2012) Effectiveness of fibrin adhesive in facial nerve anastomosis in dogs compared with standard microsuturing technique. J Oral Maxillofac Surg 70(10):2427-2432

14. Tetik C, Ozer K, Ayhan S, Siemionow K, Browne E, Siemionow M (2002) Conventional versus epineural sleeve neurorrhaphy technique: functional and histomorphometric analysis. Ann Plast Surg 49(4):397-403

15. Grinsell D, Keating CP (2014) Peripheral nerve reconstruction after injury: a review of clinical and experimental therapies. Biomed Res Int 2014:698256

16. Barros LC, Ferreira RS Jr, Barraviera SR, Stolf HO, ThomaziniSantos IA, Mendes-Giannini MJ, Toscano E, Barraviera B (2009) A new fibrin sealant from Crotalus durissus terrificus venom: applications in medicine. J Toxicol Environ Health B Crit Rev 12(8): $553-571$
17. Sandrini FA, Pereira-Júnior ED, Gay-Escoda C (2007) Rabbit facial nerve anastomosis with fibrin glue: nerve conduction velocity evaluation. Braz J Otorhinolaryngol 73(2):196-201

18. Martins RS, Siqueira MG, Silva CF, Godoy BO, Pereira JP (2005) Electrophysiological evaluation of sciatic nerve regeneration rat, with use of suture, fibrin glue or combination of both techniques. Arq Neuropsiquiatr 63(3A):601-604

19. Rochkind S, Leider-Trejo L, Nissan M, Shamir MH, Kharenko O, Alon M (2007) Efficacy of 780-nm laser phototherapy on peripheral nerve regeneration after neurotube reconstruction procedure (double-blind randomized study). Photomed Laser Surg 25(3): 137-143

20. Rochkind S, Geuna S, Shainberg A (2009) Chapter 25: phototherapy in peripheral nerve injury: effects on muscle preservation and nerve regeneration. Int Rev Neurobiol 87:445-464

21. Walsh S, Midha R (2009) Practical considerations concerning the use of stem cells for peripheral nerve repair. Neurosurg Focus 26(2), E2

22. Akgul T, Gulsoy M, Gulcur HO (2014) Effects of early and delayed laser application on nerve regeneration. Lasers Med Sci 29(1):351357

23. Thomazini-Santos IA, Barraviera SRCS, Mendes-Giannini MJS, Barraviera B B, Surgical adhesives (2001) J Venom Anim Toxins 7(2):159-171

24. Barros LC, Soares AM, Costa FL, Rodrigues VM, Fuly AL, Giglio JR, Gallacci M, Thomazini-Santos IA, Barraviera SRCS, Barraviera B, Ferreira Junior RS (2011) Biochemical and biological evaluation of gyroxin isolated from Crotalus durissus terrificus venom. J Venom Anim Toxins incl Trop Dis 17(1):23-33

25. Gasparotto VP, Landim-Alvarenga FC, Oliveira AL, Simões GF, Lima-Neto JF, Barraviera B, Ferreira RS (2014) A new fibrin sealant as a three-dimensional scaffold candidate for mesenchymal stem cells. Stem Cell Res Ther 5(3):78

26. Seabra Ferreira R Jr (2014) Autologous or heterologous fibrin sealant scaffold: which is the better choice? J Venom Anim Toxins Incl Trop Dis 20:31

27. Wang CZ, Chen YJ, Wang YH, Yeh ML, Huang MH, Ho ML, Liang JI, Chen CH (2014) Low-level laser irradiation improves functional recovery and nerve regeneration in sciatic nerve crush rat injury model. PLoS ONE 9(8), e103348

28. Anders JJ, Moges H, Wu X, Erbele ID, Alberico SL, Saidu EK, Smith JT, Pryor BA (2014) In vitro and in vivo optimization of infrared laser treatment for injured peripheral nerves. Lasers Surg Med 46(1):34-45

29. Buchaim RL, Andreo JC, Barraviera B, Ferreira Junior RS, Buchaim DV, Rosa Junior GM, de Oliveira AL, de Castro RA (2015) Effect of low-level laser therapy (LLLT) on peripheral nerve regeneration using fibrin glue derived from snake venom. Injury 46(4):655-660

30. Ganga MV, Coutinho-Netto J, Colli BO, Marques Junior W, Catalão CH, Santana RT, Oltramari MR, Carraro KT, Lachat JJ, Lopes Lda S (2012) Sciatic nerve regeneration in rats by a nerve conduit engineering with a membrane derived from natural latex. Acta Cir Bras 27(12):885-891

31. Brenner MJ, Moradzadeh A, Myckatyn TM, Tung TH, Mendez AB, Hunter DA, Mackinnon SE (2008) Role of timing in assessment of nerve regeneration. Microsurgery 28(4):265-272

32. Suri A, Mehta VS, Sarkar C (2002) Microneural anastomosis with fibrin glue: an experimental study. Neurol India 50(1):23-26

33. Whitlock EL, Kasukurthi R, Yan Y, Tung TH, Hunter DA, Mackinnon SE (2010) Fibrin glue mitigates the learning curve of microneurosurgical repair. Microsurgery 30(3):218-222

34. Sameem M, Wood TJ, Bain JR (2011) A systematic review on the use of fibrin glue for peripheral nerve repair. Plast Reconstr Surg 127(6):2381-2390 
35. Barbizan R, Castro MV, Rodrigues AC, Barraviera B, Ferreira RS, Oliveira AL (2013) Motor recovery and synaptic preservation after ventral root avulsion and repair with a fibrin sealant derived from snake venom. PLoS ONE 8(5), e63260

36. Li Y, Zhang Y, Han W, Hu F, Qian Y, Chen Q (2013) TRO19622 promotes myelin repair in a rat model of demyelination. Int $\mathrm{J}$ Neurosci 123(11):810-822

37. Moimas S, Novati F, Ronchi G, Zacchigna S, Fregnan F, Zentilin L, Papa G, Giacca M, Geuna S, Perroteau I, Arnež ZM, Raimondo S (2013) Effect of vascular endothelial growth factor gene therapy on post-traumatic peripheral nerve regeneration and denervationrelated muscle atrophy. Gene Ther 20(10):1014-1021

38. Machado EG, Issa JP, Figueiredo FA, Santos GR, Galdeano EA, Alves MC, Chacon EL, Ferreira Junior RS, Barraviera B, Cunha MR (2015) A new heterologous fibrin sealant as scaffold to recombinant human bone morphogenetic protein-2 (rhBMP-2) and natural latex proteins for the repair of tibial bone defects. Acta Histochem 117(3):288-296

39. Cartarozzi LP, Spejo AB, Ferreira RS Jr, Barraviera B, Duek E, Carvalho JL, Góes AM, Oliveira AL (2015) Mesenchymal stem cells engrafted in a fibrin scaffold stimulate Schwann cell reactivity and axonal regeneration following sciatic nerve tubulization. Brain Res Bull 112:14-24

40. Xu K, Terakawa S (1999) Fenestration nodes and the wide submyelinic space form the basis for the unusually fast impulse conduction of shrimp myelinated axons. J Exp Biol 202(Pt 15): 1979-1989

41. Waitayawinyu T, Parisi DM, Miller B, Luria S, Morton HJ, Chin SH, Trumble TE (2007) A comparison of polyglycolic acid versus type 1 collagen bioabsorbable nerve conduits in a rat model: an alternative to autografting. J Hand Surg [Am] 32(10):1521-1529

42. Moore AC, Mark TE, Hogan AK, Topczewski J, LeClair EE (2012) Peripheral axons of the adult zebrafish maxillary barbel extensively remyelinate during sensory appendage regeneration. J Comp Neurol 520(18):4184-4203

43. Shin DH, Lee E, Hyun JK, Lee SJ, Chang YP et al (2003) Growthassociated protein-43 is elevated in the injured rat sciatic nerve after low power laser irradiation. Neurosci Lett 344:71-74

44. Câmara CN, Brito MV, Silveira EL, Silva DS, Simões VR, Pontes RW (2011) Histological analysis of low-intensity laser therapy effects in peripheral nerve regeneration in Wistar rats. Acta Cir Bras 26(1):12-18 